\title{
ACTUALIZATION OF GIFTED SCHOOLCHILDREN'S INTENTIONAL EXPERIENCE IN THE PROCESS OF MASTERING GEOMETRIC CONCEPTS: FROM SUPPORT TO ACTIVITY MECHANISM
}

\author{
ATUALIZAÇÃO DA EXPERIÊNCIA INTENCIONAL DE ALUNOS SUPERDOTADOS \\ NO PROCESSO DE DOMINAR CONCEITOS GEOMÉTRICOS: DO SUPORTE AO \\ MECANISMO DE ATIVIDADE
}

\author{
ACTUALIZACIÓN DE LA EXPERIENCIA INTENCIONAL DE LOS ESCOLARES \\ SUPERDOTADOS EN EL PROCESO DE DOMINAR LOS CONCEPTOS \\ GEOMÉTRICOS: DEL APOYO AL MECANISMO DE ACTIVIDAD
}

\author{
Natalia Georgievna PODAEVA ${ }^{1}$ \\ Pavel Alexandrovich AGAFONOV ${ }^{2}$
}

\begin{abstract}
People's intellectual abilities become a powerful civilization resource. Therefore, intellectually gifted schoolchildren's development should be the focus of the state educational policy. Russian opinion leaders interpret the phenomenon of giftedness as a systemic quality that describes the child's psyche as a whole. Such an approach turns into a priority to update and enrich the gifted schoolchildren's intentional experience during geometry teaching. It assumes the development of a particular subjective state of orientation and selectivity of individual cognitive activity in preferences. This unique state becomes a mental activity mechanism, not just an accessory. The statistical data analysis confirms the hypothesis: the efficiency of actualizing gifted schoolchildren's intentional experience in the form of their individual dispositions, beliefs, and emotional assessments while solving geometric problems during academic competitions is provided by specifically organized educational activities. It positively correlates with the level of mental activity development during mastering the activity methods with geometric concepts.
\end{abstract}

KEYWORDS: Geometry teaching. Intentional experience. Mental activity. Educational environment. Integral thinking units.

RESUMO: No mundo moderno, as habilidades intelectuais das pessoas se tornam um poderoso recurso da civilização. Portanto, o desenvolvimento de alunos com superdotação intelectual deve ser o foco da política educacional do estado. Os principais formadores de opinião da Rússia interpretam o fenômeno da superdotação como uma qualidade sistêmica que descreve a psique da criança como um todo. Tal abordagem prioriza a atualização e enriquecimento da experiência intencional de alunos superdotados durante o ensino de geometria. Isso pressupõe o desenvolvimento de um determinado estado subjetivo de orientação e seletividade da atividade cognitiva individual baseada em preferências. A análise de dados estatísticos confirma a eficiência de atualizar a experiência intencional de

\footnotetext{
${ }^{1}$ Bunin Yelets State University (BYSU), Yelets - Russia. Professor of Department of Mathematics and its Teaching Methodics. ORCID: https://orcid.org/0000-0002-9491-5011. E-mail: podaevan@bk.ru

${ }^{2}$ SBEI Secondary School No. 2070, Moscow - Russia. Mathematics teacher. ORCID: https://orcid.org/00000002-8934-0233. E-mail: pavel.a.agafonov@rambler.ru
} 
alunos superdotados na forma de suas disposições individuais, crenças e avaliações emocionais enquanto resolve problemas geométricos durante competições acadêmicas é fornecida por atividades educacionais especificamente organizadas. Isso se correlaciona com o desenvolvimento da atividade mental durante o domínio dos métodos de atividade com conceitos geométricos.

PALAVRAS-CHAVE: Ensino de geometria. Experiência intencional. Atividade mental. Ambiente educacional. Unidades de pensamento integral.

RESUMEN: Las habilidades intelectuales de las personas se convierten en un recurso poderoso. El desarrollo de los escolares intelectualmente superdotados debería ser el centro de la política educativa estatal. La opinión principal rusa interpreta el fenómeno de la superdotación como una cualidad sistémica que describe la psique del niño en su conjunto. Este enfoque prioriza la actualización y el enriquecimiento de la experiencia intencional de los escolares superdotados durante la enseñanza de la geometría. Asume el desarrollo de un estado subjetivo particular de orientación y selectividad de la actividad cognitiva individual en preferencias. La eficiencia de actualizar la experiencia intencional de los escolares superdotados en la forma de sus disposiciones individuales, creencias y evaluaciones emocionales mientras se resuelven problemas geométricos durante las competencias académicas es proporcionada por actividades educativas especificamente organizadas. Se correlaciona con el desarrollo de la actividad mental durante el dominio de los métodos de actividad con conceptos geométricos.

PALABRAS CLAVE: Enseñanza de geometria. Experiencia intencional. Actividad mental. Ambiente educativo. Unidades de pensamiento integral.

\section{Introduction}

In the modern world, people's intellectual abilities became a powerful civilization resource. New knowledge, technologies, and social life values are born in individual or group consciousness due to intellect operation. The future of any state is predetermined by the number of intellectuals in its population. At the same time, the intellectual resource is being formed for a long time, being a long-term factor of social development influence. Therefore, intellectually gifted schoolchildren's development should be the focus of the state educational policy. The thing is that the modern world is changing dramatically, while the education system does not adapt to these changes promptly enough. The obsolete ideas in education do not conform to the new global changes in the world and society. And even if we rebuild this system to comply with the requirements of today, it will become outdated by the time today's first graders leave school. Awareness of these changes requires structuring new concepts and models of education development enabling keep up with the modern world and focusing on a changeable future.

RPGE- Revista on line de Política e Gestão Educacional, Araraquara, v. 16, n. 2, p. 1311-1327, May/Aug. 2021. e-ISSN: 1519-9029 
In this study, mathematically gifted schoolchildren development is considered in a post-non-classical general scientific paradigm that shifts the attention focus to integrity retention, the ratio and mutual influence of the rational and irrational, conscious and unconscious within the cognition process. In the history and philosophy of science, there are three paradigms of scientific rationality - classical, non-classical, and post-non-classical - that are associated with three periods in scientific knowledge development and with the relevant thinking styles (STEPIN, 2007).

A specific feature of the classical thinking style is the reliance on the deductiveaxiomatic method in structuring a stable classical world image. However, it is precisely the stability of classical samples that has become one of the reasons for the impossibility of using them in the study of dynamic systems due to their methodological limitations. As a result, the classical paradigm has undergone criticism and revisionism.

The non-classical rationality type is remarkable, first, for its pluralism principles, subjectivism, and communicativeness. The awareness of regularity characterizes the nonclassical thinking style expressed depending on the nature of the knowledge obtained using the selected subjective method of intelligent behavior and individual cognitive approach. Regularity awareness also depends on the ability to evaluate the knowledge provided by science in the context of their social value and moral norms, on understanding the sense of this knowledge within a particular historical context. The main educational process objective is developing a unique creative child's personality following his cognitive dispositions and preferences.

Invoking post-non-classics, which shifts the attention focus to the integrity retention and the correlation and mutual influence of the rational and irrational within the cognition process, is especially relevant for mathematical education. It is well known that mathematics is outstanding for its abstractness, the theoretical (but not empirical) nature of its subject, and its dialectical "ascension" from the abstract to the specific. The context of a mathematician's thinking is unambiguous, purely logical (in contrast to the ambiguous, figurative context of theoretical but practicallyapplied knowledge. The studies of the recent decades (ROTENBERG; BONDARENKO, 1989; ZEMLIAKOV, 2005) evidence that left-hemisphere thinking is overused in the modern world. This thinking features the verbal, logical, information-operating approach reduced to specific contexts. However, the human brain's right hemisphere can fully perceive a multi-valued context while integrating all the contradictory connections of the surrounding world. It oversees a multi-valued "self-image" generation (ROTENBERG, 2001). 
The leading Russian experts interpret the giftedness phenomenon as a systemic quality that characterizes the child's psyche as a whole (BOGOYAVLENSKAYA; SHADRIKOV, 2003). At the same time, it is noted that it is the personal orientation and the value system that cater to individual talent development. In this regard, the sociocultural approach to education is actualized, in which the value is regarded as a core category. Activity is considered a culture microstructure and a cultural phenomenon. The internal value development dynamics and the phases of these dynamics are also highlighted. Such an approach turns into a priority to update and enrich the gifted schoolchildren's intentional (emotional and evaluative) experience during geometry teaching. It assumes the development of a particular subjective state of orientation and selectivity of individual cognitive activity in preferences, beliefs, and attitudes. This subjective state becomes a cognitive activity mechanism, not just an accessory.

The study objective describes the model of gifted schoolchildren's intentional experience actualization in mastering geometric concepts using the resource of the GeoGebra dynamic system (ARBAIN; SHUKOR, 2015; TAKACI; STANKOV; MILANOVIC, 2015; THAMBI; EU, 2013; ZAKARIA; LEE, 2012; ZENGIN; FURKAN; KUTLUCA, 2012). The aim is achieved by solving the following tasks: to clarify the concept of "gifted schoolchildren's intentional experience actualization in the process of mastering geometric concepts"; to justify the psych didactic environment for the efficient intentional experience actualization; to determine the levels, stages, and patterns of intentional experience actualization and the formation of the value-semantic students' sphere; to describe the experimental work results within the course "The selected problems for geometry academic competitions" for gifted 8-9 grade students using the resource of the GeoGebra dynamic system as a component of the electronic educational environment (EEE).

\section{Literature review}

The analysis of "learning" concept views formation resulted in identifying three approaches: cognitive approach - learning as cognition (RUBINSTEIN, 1999) behavioral approach - learning as experience acquisition (TOLMAN; BRUNSWIK, 1935) and sociocultural approach - learning as cultural values development (DOBRENKOV, 2003).

The psychological school supervised Piaget (1966) developed a cognitive-behavioral concept. Learning is interpreted as the acquisition of cognitive experience, the formation of skills as mental actions, as the improvement of the mental, cognitive abilities inherent to personality development. Human intelligence is treated as a system of derivatives of objective 
activities and operations that interact with each other to form a specific integral structure. The experience acquisition deems to be the learning outcome (PIAGET, 1966).

The research results of many Russian and foreign psychologists and dialecticians have shown that, on the one hand, thinking development occurs spontaneously during mathematics teaching. On the other hand, mathematical thinking is not only one of the most significant cognitive activity components. On the other hand, without purposeful mathematical thinking development achieving effective results in students' mastering the system of mathematical knowledge, skills and abilities are impossible.

As a result of the analysis of the development of views on learning in the sociocultural aspect, some trends have been identified. The learning process is considered a sociocultural phenomenon (SOROKIN, 1941). Social values are an essential social factor in learning (SHCHEDROVITSKY, 2003). The essence of education's sociocultural function is considered a regulation of relations between an individual and social experience via specific mechanisms, comprising value orientations and a value-focused approach (SHIRSHOV, 2001).

Reviewing the concepts and ideas that comprise their understanding of social knowledge assimilation by a particular person, we would like to mention the concept of sociocultural mathematics teaching (PODAEVA et al., 2014; PODAEVA; PODAEV, 2019a). In this context, the authors claim that in modern education, the recognition of the sociocultural function of teaching means the existence of a sociocultural technology aimed at transferring the socially and personally significant activity experience structured as knowledge, capacities, skills, and basic cultural abilities.

I. N. Golitsyna's research touches upon the use of digital media in educational process (PODAEVA et al., 2014). Modular digital educational environments are examined in papers (DAVYDOV, 1992; DALINGER, 2006; KABANOVA-MELLER, 1962; METELSKY, 1982; SARANTSEV, 1999; SLEPKAN, 1983; USTILOVSKAYA, 2008; YAKIMANSKAYA, 2004).

The implementation of the theoretical approach requires the involvement of many theoretical search heuristics described by Grudenov (1987), Poya (1975), Friedman (1989), and many other authors. Engaging most of them requires a reflexive analysis of the problem situation and referring to the previous experience of resolving such cases. 


\section{Methods}

While analyzing the categorial apparatus of this study, in the structure of the symbolic sign system "geometric concept," we tentatively distinguish the following components: verbal and logical component (ideal characteristics - properties, attributes); visual component (material and objects items and models in the actual world - the geometric concept naturalization, as well as sign and symbolic structures; activity component that comprises formal-logical and figurative image actions and operations. Finally, the emotional component of geometric concepts reveals the role of value knowledge expressed as value judgments and developed based on emotional and evaluative (intentional) experience as Poincaré and Hadamard (1949) puts it, the intuition and esthetic feeling act in geometry as a sieve that sifts various combinations of ideas since the most valuable varieties turn out to be mathematically the most beautiful.

This way, in the activity component structure of a geometric concept, we distinguish the content-related plane of the concept, the sign, and intentional attitude planes.

The first category includes cognitive objectively meaningful practical and actual operations with a geometric object enabling to distinguish the spatial relations in it (as if not noticing the others) and to handle them as images. As noted by Mordukhai-Boltovskoy (1950), the geometrician does not remember the visual image of the drawing. He remembers only the relative positioning of objects and their parts.

The second category includes formal operations that begin with ready-made knowledge and language expressions enabling you to move from one property to another but not to extract new content in the object. That is, they are not cognitive. As shown in studies by Piaget (1969), formal operations are finally formed in adolescence - they are mental categorical and logical actions that facilitate structuring hypothetical and deductive reasoning without reference to a specific situation (thinking in the mode "as if..."). In mastering geometric concepts, the formal operations - analysis, generalization, comparison on various bases relying on conceptual knowledge - ensure the classification of geometric shapes (PASANI, 2019).

Finally, the intentional plane related to an emotional impression as an experience modality includes, as well as other things, the intuitive techniques and a specific geometrician's esthetic sense implemented as an intentional experience of gifted schoolchildren. 
The study claims that in establishing geometric concepts, the leading role should be assigned first and foremost to the activity and value components, not only to and not so much to the verbal logical, and visual components of the "geometric concept" system. In other words, the conceptual cognitive activity should be done in image structures. At the same time, the logical operations and the intentional experience of the learner should be its development mechanism and factor. The holistic procedures should be the thinking units. They combine actual, formal operations and intentional techniques.

Psychologists define the intentional experience as a system of education that incorporates three groups of mental structures (individual preferences, personal beliefs, and attitudes). They are fundamentals of individual intellectual predispositions. The main objective of intentional experience is criteria formation to select the ways to solve the problems and intellectual activity methods, etc.

Individual preferences are individual cognitive predispositions that manifest themselves in the selectivity of students' choice to select the ways to solve the problems and intellectual activity methods.

Mental attitudes are subjective states that manifest themselves in their intellectual work's sensory and emotional experiences (a sense of search orientation, a sense of solution clarity, and proximity).

The personal beliefs manifest themselves as the ability to "see" the problem. It means an independent problem statement as an action of an intellectually proactive person. It also includes intuition as the ability to come to an intellectual result unconsciously based on the emergence of subjective confidence and conviction in the absolute correctness of a particular view of the decisions made, on the adequacy of situation assessment like "I do not know why, but I am sure that...", the intuitive process refers to right-hemisphere activity. It has a simultaneous (collapsed, spasmodic) nature, and it practically is not subject to verbalization.

Let us clarify that by the actualization of gifted schoolchildren's intentional experience in mastering the geometric concepts, we mean developing a particular subjective state of orientation and selectivity of individual cognitive activity in the form of preferences, beliefs, and attitudes. It acts as one of the mechanisms of conceptual mathematical action and not just its accessory. The opinion of A. Poincare on this account is widely known. He remarked that the proof is syllogisms arranged in a specific order, and only if there is a "sense of this order," one can embrace the whole set of arguments (POINCARE, 1983, p. 36-37). 


\section{Discussion}

The system model of gifted schoolchildren's intentional experience actualization in mastering the geometric concepts has been developed in line with the social and cultural concept of mathematical education (PODAEVA; PODAEV, 2019b). Under the sociocultural concept, the procedural aspect of students' personal and socially oriented activities for mastering mathematical content is based on the concept of step-by-step formation of mental actions (GALPERIN, 1985). The authors of the sociocultural concept distinguish the levels of understanding, assimilation, and use. These levels are an integral system of formation stages for mental actions that can also be described as didactic tasks and patterns. Level 1 "Understanding" is implemented at the stages of awareness, comprehension, and generalization Level 2, "Assimilation," comprises the patterns of memorization, systematization, and forgetting prevention. Level 3 "Use" is realized at the stages of skills' formation and their common and creative uses (PODAEVA; PODAEV, 2019b).

In the context of the sociocultural concept, the primary task is forming a semantic value sphere in students. This sphere is a system formation. Its structure comprises cognitive (value representations), emotional (value relations), and behavioral (value orientations and personal meanings) components. Obviously, the actualization and enrichment of their intentional experience are of great importance for forming the semantic value sphere in gifted schoolchildren. Lerner (1992) mentioned, the vividness of material presentation, image richness, esthetically designed visual aids, encouragement of overcoming difficulties, memorable material from science history, elegant problem solutions are the vehicles for value system formation. On the other hand, for the intentional experience to be able to function not only as an accessory of cognitive and scientific activity but also as the mechanism and factor of development, it needs to be a projection of the main stages and patterns of schoolchildren's value and semantic sphere development. In other words, the traditional formal deductive approach should be supplemented by a sociocultural one, wherein the development of conceptual cognitive activity is regarded as a multifunctional didactic system.

Table 1 - Actualization of intentional experience and formation of the value semantic sphere in gifted schoolchildren

\begin{tabular}{|c|c|c|c|}
\hline $\begin{array}{l}\text { Mental } \\
\text { structures } \\
\text { as part of } \\
\text { intentional } \\
\text { experience }\end{array}$ & $\begin{array}{l}\text { Regularities of mental } \\
\text { structures' actualization and } \\
\text { enrichment }\end{array}$ & $\begin{array}{l}\text { Components of } \\
\text { value semantic } \\
\text { sphere }\end{array}$ & $\begin{array}{l}\text { Developmental regularities of value } \\
\text { semantic sphere components }\end{array}$ \\
\hline
\end{tabular}

RPGE- Revista on line de Política e Gestão Educacional, Araraquara, v. 16, n. 2, p. 1311-1327, May/Aug. 2021. e-ISSN: $1519-9029$ DOI: https://doi.org/10.22633/rpge.v25i2.15449 


\begin{tabular}{|c|c|c|c|}
\hline $\begin{array}{l}\text { Individual } \\
\text { preferences }\end{array}$ & $\begin{array}{l}\text { The development of individual } \\
\text { cognitive predispositions } \\
\text { manifests itself in the } \\
\text { selectivity of students' choice } \\
\text { of specific ways to solve the } \\
\text { problems and intellectual } \\
\text { activity methods. }\end{array}$ & Cognitive & $\begin{array}{l}\text { Formation of value representations that are } \\
\text { knowledge about mathematical categories, } \\
\text { objects, and methods. } \\
\text { Value representations should be included in } \\
\text { a personally recognized system of values via } \\
\text { their reflection in consciousness. }\end{array}$ \\
\hline $\begin{array}{l}\text { Mental } \\
\text { attitudes }\end{array}$ & $\begin{array}{l}\text { The development of sensory } \\
\text { and emotional experiences of } \\
\text { their intellectual work (a sense } \\
\text { of search orientation, solution } \\
\text { clarity, and proximity). }\end{array}$ & Emotional & $\begin{array}{l}\text { Formation of students' value attitude to } \\
\text { mathematical knowledge as a carrier of } \\
\text { cultural values. In the process of learning, a } \\
\text { system of value (evaluative) knowledge is } \\
\text { gradually formed. It creates the effect of } \\
\text { student's "personal presence." The student } \\
\text { expresses oneself in the form of value } \\
\text { judgments using the words such as } \\
\text { "important (useless)," "rational (irrational)," } \\
\text { "elegant (cumbersome)," "curious } \\
\text { (uninteresting)," etc. Relying on the sensory } \\
\text { and emotional method of information } \\
\text { encoding is assumed. It is formed by using } \\
\text { questions that lead the students to dynamic } \\
\text { assessments of the subject material. }\end{array}$ \\
\hline $\begin{array}{c}\text { Personal } \\
\text { beliefs }\end{array}$ & $\begin{array}{l}\text { Development of the ability to } \\
\text { "see" the problem (an } \\
\text { independent problem } \\
\text { statement as an action of an } \\
\text { intellectually proactive } \\
\text { person), subjective confidence } \\
\text { and conviction in the absolute } \\
\text { correctness of a particular } \\
\text { view of the decisions made, a } \\
\text { conviction in the adequacy of } \\
\text { situation assessment like "I do } \\
\text { not know why, but I am sure } \\
\text { that...", flexibility and } \\
\text { adaptability, initiative and } \\
\text { self-regulation, productivity } \\
\text { and responsibility, leadership. }\end{array}$ & Behavioral & $\begin{array}{l}\text { The value acceptance will contribute to the } \\
\text { formation of value orientations, personal } \\
\text { meanings, and the student's personality } \\
\text { dynamic. The values assimilated by the } \\
\text { student are realized in their behavior and } \\
\text { activity. It is essential that using specially } \\
\text { selected tasks, and the students could learn } \\
\text { their right to choose the manner of } \\
\text { educational behavior complying with their } \\
\text { preferences, assessments, and value attitude. }\end{array}$ \\
\hline
\end{tabular}

Source: Prepared by the authors

What will change with the revision of the view of the process of gifted schoolchildren's geometric training? Understanding of the main aspects of mathematical competition training will change. Let's have a look at these differences illustrated by answers to some questions.

Table 2 - Questions and answers list

\begin{tabular}{|l|l} 
Formal deductive approach & Sociocultural approach \\
\hline
\end{tabular}

Who should be the subject of pedagogical activity for mathematical training of gifted teenagers (teaching style, educational paradigm)? 
A professional mathematician with a high level of scientific qualification who consistently and correctly communicates the historically accumulated experience of mathematical knowledge, considering the age-related features of students' development.

In what form should the educational content be presented?

In the form of an educational and didactic complex,
comprising varied tasks (informative, explanatory,
reasoning, problematic, "impossible"), different forms of
educational information presentation (verbal and symbolic,
visual, subject and practical, emotional and evaluative),
means of organizing various types of activities (reproductive,
research, creative).

What thinking qualities does the educational process develop?

Analyticity, linearity, successiveness, Synthetics, non-linearity, expansion, simultaneity, image and convolution, sign and symbolic expression form, intuitive form of expression, inductance, dependence on deductive nature, independence from context. context.

What are the means of teaching mathematically gifted students?

Psychodidactic complex of aids (motivation for concepts' introduction, dialogue, construction of individual educational trajectories based on input diagnostics, as well as support for students' movement along these trajectories, a joint

Mathematical knowledge that a priori has a developing effect. reflection of the achieved results, a variable educational environment at the level of learning content that provides an opportunity for a gifted student to select an intelligent behavior method following his cognitive predispositions, preferred decision-making techniques, selection of control forms, selectivity of specific topics).

What is the target value of the educational and pedagogical process?

Along with knowledge, abilities, and skills, the maturity of individual's cultural basic skills, an open cognitive position

Knowledge, abilities, skills (the ability to solve problems of mathematical contest level). as a mental attitude to the world, when the individual worldview is featured by flexibility, variability of subjective ways of understanding the same event, tolerance towards paradoxical information, willingness to accept and to discuss another point of view, etc.

Source: Prepared by the authors

The developed model of the system of actualization of gifted schoolchildren's intentional experience in the process of their mastering geometric concepts comprises the following subsystems:

- The technological subsystem represented by a specific resource on GeoGebra.ru platform;

- The methodological subsystem is implemented through the co-organization of students' purposeful educational activities based on formed value semantic sphere.

In procedural terms, this model is cyclic and contains:

RPGE- Revista on line de Política e Gestão Educacional, Araraquara, v. 16, n. 2, p. 1311-1327, May/Aug. 2021. e-ISSN: 1519-9029 
- The psychodidactic cycle ensures the involvement of subjects in the process of actualizing and enrichment of mental structures based on an integral cycle containing three phases: 1) Development of individual cognitive predispositions; 2) Development of sensory and emotional experiences of their intellectual work; 3) Development of the ability to "see" the problem, intuition (subjective confidence and conviction in the correctness of a specific view of the decisions made, the conviction in the adequacy of situation assessment);

- The semantic value cycle reflects the structure of the value semantic sphere. It comprises the following successive phases: the cognitive phase - providing value representations as knowledge about mathematical categories and methods; the emotional phase - ensuring the value-based students' attitude to mathematical knowledge as a carrier of cultural values; the behavioral phase - providing value orientations and personal meanings as the implementation of values accepted by students in behavior and activity;

The final cycle focuses on checking the achieved level of intentional experience actualization manifested in the complex development of students' individual preferences, personal beliefs, mental attitudes, acting as one of the cognitive and scientific activity mechanisms and not just an accessory.

\section{Findings}

In the process of experimental work, the success of individual preferences formation was ensured by an unstable educational environment at the level of academic content - the variability of subjective ways of understanding the same event. It provides an opportunity for a gifted student to select a method of intelligent behavior following his cognitive predispositions and preferences, the control form selection, and the selectivity of specific topics. The task of individualization of teaching was set. The problems were selected so that students with different mathematical capacities and cognitive predispositions could choose the line of their intelligent behavior that complies most fully with their preferences. Different approaches to solving the same problem were considered. Much attention was paid to the game approach. It should be mentioned that many researchers (PETER, 1968; PISAREVSKY; KHARIN, 2004) consider the game to be one of the mathematics sources. They identify mathematics with the "great game". Various didactic games were used: games with strict rules (mathematical lotto, working with ciphers, computer games), role-playing games (competitions, tournaments), correctional games (exercise games), intellectual games 
(imaginary experiment, computer experiment, finding a solution in an "impossible situation" etc.).

Thus, one of the forms is a mathematical brain ring. The children are split into teams; the captains hold their hands on the button. After the question was read aloud, the team that managed to press the button first is the first to answer. In case of a wrong answer, the question is played between the remaining teams. Each question has its score, and the team wins with the highest number of scores. Another form is a mathematical battle. The teams receive tasks (about 8). They are given about 3 hours for a joint solution and discussion. Two teams compete. The captains play the right of the first call. The opposing team is called for a specific task, and the call may be accepted and a speaker comes out from the team, he is opposed by an opponent. The speaker tells the solution, the opponent asks questions and evaluates the solution. After completion of the report and the verdict, the jury distributes the scores for this task. If the opposing team does not accept the challenge, the task is told by the team's speaker, who had challenged the opponent.

So, studying the topic "The Task of Apollonius" is arranged in the form of a roleplaying game. The game characters are divided into groups. They solve the problem by brainstorming. Each group justifies its solution method (analytical, geometric, using projective geometry). Students choose a group as they want based on their preferences and cognitive predispositions (analytics, synthesists, etc.). They participate in the solution discussion. Historicity was used to ensure the mental attitudes' development (sensory and emotional experiences of students' intellectual work). The historicity approach assumed information about objects included in the cultural and historical zone in the educational process. It facilitated access to value-oriented learning. Mathematical knowledge acted as a form of mastering cultural values, according to Sharygin (2004, p. 73), geometry is a phenomenon of universal culture: "Some geometry theorems are among the oldest monuments of the world culture. A person cannot truly develop culturally and spiritually if he did not study geometry at school; geometry arose not only from practical but also from human spiritual needs".

Turning to various scientific methods of solving the same problems as cultural and historical analogs, we examined such a fundamental educational object as the parallel axiom. The axiom genesis is inseparably associated with the fifth Euclid's postulate proving and Lobachevsky geometry. For example, before solving the problems, we delved into the history of establishing the fifth Euclid's postulate for the students to see the role of the problem of its proof in world culture. The historiographical information was stipulated that since the time of 
Euclid and until the end of the XIX century, many attempts were made to prove the fifth postulate by O. Khayyam, Legendre etc. (BOGOMOLNY, 2018). At the same time, the author of the proof mistakenly proceeded from assumptions that, as it was discovered later, were the equivalent of the fifth postulate. Thus, the attempts failed, but as a result, several remarkable theorems of absolute geometry were proven. Legendre (1867) subsequently systematized them. We also mentioned an alternative analog of the parallelism theory interpretation by Lobachevsky (1829). The students were given their cognitive position depending on one of the two cultural and historical parallel axiom interpretations - Euclid's geometry and absolute geometry.

We used empirical methods (the method of summing up problems, delayed proof, step-by-step increase in theoretical strictness level) as didactic techniques aimed at personal beliefs development (the ability to "see" the problem, intuition), directly or indirectly related to the possibility of using in the educational process of scientific and educational software products called Dynamical Geometry Software or interactive geometric environment. The method of "summarizing tasks" was reduced to setting a series of tasks to students for experiments with geometric objects models in the GeoGebra environment. They precede the theoretical solution of the problem to create the foundation of initial ideas about the manifestation of patterns formalized in the process of theoretical solution.

The "delayed proof" technique assumed the presentation of theoretical items declaratively (without proof) or by replacing the proof with a demonstration of statements' truth in a particular interpretation or using specific examples in GeoGebra environment.

The method of "gradual increase in theoretical strictness level" is based on the idea of soft models proposed by academician Arnold (2000). He suggested replacing strict definitions with concepts' descriptions at the first stages and of proof replacement with truth-like reasoning or a visual demonstration of regularities' manifestation.

The experimental work outcomes bring together the issues of the impact of a specially organized methodology using the dynamic geometry systems on actualization and enrichment of the main components of intentional experience that form the basis of students' productive intellectual development in solving geometric problems at mathematical contests.

\section{Conclusion}

The article describes the model of the system of actualization of gifted schoolchildren's intentional experience in the process of mastering geometric concepts that 
had been developed in line with the sociocultural vision of mathematical education. The idea is claimed that the intentional experience can act as an accessary of cognitive conceptual activity and its mechanism and factor of its development. But the intentional experience is suitable for it only being a projection of the main stages and patterns of the value semantic sphere development in gifted schoolchildren in terms of its content, practices, and structure. The factors, methods, and techniques that ensure the actualization of trainee subjects' emotional and evaluative experiences are examined. The results of schoolchildren's diagnostics evidence for a significant correlation between the level of technique maturity in handling geometric concepts while solving the geometric problems at mathematical contests and the actualization level of intentional experience in trainee subjects.

ACKNOWLEDGMENTS: The research was done within the framework of the grant issued for implementation of Scientific Project No. 19-313-90018 of the Russian Foundation for Basic Research (RFBR) "Methodological support of the process of mastering geometric concepts by schoolchildren in an electronic educational environment". This Project was supported by the RFBR based on the results of a project competition for the best fundamental scientific research accomplished by young post-graduate scientists.

\section{REFERENCES}

ARBAIN, N.; SHUKOR, N. A. The effects of GeoGebra on Students achievement. ProcediaSocial and Behavioral Sciences, v. 172, p. 208-214, 2015.

ARNOLD, V. I. Hard and soft mathematical models. Moscow: Moscow Center for Continuing Mathematical Education, 2000.

BOGOMOLnY, A. The Fifth Postulate. Attempts to Prove. Cut the Knot, 2018 Available: https://www.cut-the-knot.org/triangle/pythpar/Attempts.shtml Access: 10 May 2021.

BOGOYAVLENSKAYA, D. B.; SHADRIKOV, V. D. The working concept of giftedness. Moscow: Magistr, 2003.

DALINGER, V. A. Methods of teaching the proof of mathematical propositions to students. Moscow: Prosveshchenie, 2006.

DAVYDOV, V. V. Psychological theory of educational activity and methods of primary education based on meaningful generalization. Tomsk: "Peleng" Publishing House, 1992.

DOBRENKOV, V. I. Society and education. Moscow: INFRA-M, 2003.

RPGE- Revista on line de Política e Gestão Educacional, Araraquara, v. 16, n. 2, p. 1311-1327, May/Aug. 2021. e-ISSN: 1519-9029 
FRIEDMAN, L. M.; TURETSKY, E. How to learn to solve problems. Moscow:

Prosveshchenie, 1989.

GALPERIN, P. Y. Methods of teaching and mental development. Moscow:

Prosveshchenie, 1985.

GRUDENOV, Y. I. Psycho-didactic fundamentals of teaching mathematics methods. Moscow: Pedagogika, 1987.

KABANOVA-MELLER, E. N. Psychology of knowledge and skills formation in students. Moscow: APN RSFSR, 1962.

KAIVO-OJA, J.; ROTH, S. The Technological Future of Work and Robotics. Econstor, 2015. Available: http://hdl.handle.net/10419/118693 Access: 10 May 2021.

LEGENDRE, A. M. Elements of Geometry. Baltimore: Kelly \& Piet Publishers, 1867. Available: https://archive.org/details/cu31924001166341/page/n5/mode/2up Access: May 10, 2021.

LERNER, I. Y. Methodological problems of the didactic theory of textbook construction. In LERNER, I. Y.; SHAKHMAEV, N. M. What should a textbook be: Didactic structuring principles Part 1. Moscow: Publishing House of the Russian Academy of Sciences, 1992. p. $7-26$.

METELSKY, N. V. Didactics of mathematics. Minsk: Belarus State University Publishing, 1982.

PASANI, C. F. Analyzing Elementary School Students Geometry Comprehension Based on Van Hiele's Theory. Journal of Southwest Jiaotong University, v. 54, n. 5, p. 1-11, 2019. Available: http://jsju.org/index.php/journal/article/view/389. Access: 10 May 2021.

PETER, R. The game with infinity. Moscow: Progress, 1968.

PIAGET, J. How children form mathematical concepts. Psychology Issues, v. 4, p. 121-126, 1966.

PIAGET, J. Selected psychological works. Psychology of intelligence. Moscow:

Prosveshchenie, 1969.

PISAREVSKY, B. M.; KHARIN, V. T. Talks about mathematics and mathematicians. Moscow: Fizmatlit, 2004.

PODAEVA, N. G.; PODAEV, M. V. Updating the content of school mathematical education: a sociocultural approach. St. Petersburg: "Lan"” Publishing House, 2014.

PODAEVA, N. G.; PODAEV, M. V.; AGAFONOV, A. P. Formation of concepts in the process of teaching geometry to students in e-learning environment. "Concept" Scientific Methodical Electronic Journal, n. 6, p. 10-25, 2019. Available: http://ekoncept.ru/2019/191040.htm Access: 10 May 2021. 
PODAEVA, N. G.; PODAEV, M. V.; AGAFONOV, P. A. The social and cultural approach to forming geometric concepts among schoolchildren. Amazonia Investiga, v. 8, n. 20, 2019. Available: https://amazoniainvestiga.info/index.php/amazonia/article/view/175 Access: 10 May 2021.

POINCARE, A. About science. Moscow: Nauka, 1983.

POINCARÉ, H.; HADAMARD, J. An essay on the psychology of invention in the mathematical field. Princeton: Princeton University Press, 1949.

POYA, D. Mathematics and plausible reasoning. Moscow: Nauka, 1975.

ROTENBERG. V. S. "I image” and behaviour. Tel Aviv, 2001.

ROTENBERG. V. S.; BONDARENKO, S. M. Brain. Training. Health: Teacher's book. Moscow: Prosveshchenie, 1989.

RUBINSTEIN, S. L. Fundamentals of general psychology. St. Petersburg: "Peter" Publishing House, 1999.

SARANTSEV, G. I. Goals of teaching mathematics in secondary school in modern conditions. Mathematics at school, n. 6. p. 36-41, 1999.

SHARYGIN, I. F. Does the school of the XXI century need geometry? Mathematics at school, n. 4, p. 72-79, 2004.

SHCHEDROVITSKY, G. P. Processes and structures in thinking (a course of lectures). From the archive of G. P. Shchedrovitsky. Moscow, 2003. v. 6.

SHIRSHOV, I. E. Personality - Freedom - Creativity. In: Humanization of education process: personal motive and creative development. Report theses of scientific conference in Bobruisk, March 29-30, 2001. Minsk: Belarus State Economic University Publishing, 2001.

SLEPKAN, Z. I. Psychological and pedagogical foundations of teaching mathematics. Kiev: Radianska shkola, 1983.

SOROKIN, P. A. Social and Cultural Dynamics. Volume IV: Basic Problems, Principles, and Methods. New York: Bedminster Press, 1941.

STEPIN, V. S. On the philosophical foundations of synergetics. Synergetic paradigm. Synergetics of education. Moscow: Progress-tradition, 2007. p. 97-102.

TAKACI, D.; STANKOV, G.; MILANOVIC, I. Efficiency of learning environment using GeoGebra when calculus contents are learned in collaborative groups. Computers $\&$ Education, v. 82, p. 421-431, 2015.

THAMBI, N.; EU, L. K. 2013 Effect of students' achievement in fractions using GeoGebra. SAINSAB, v. 16, p. 97-106. 
TOLMAN, E. C.; BRUNSWIK, E. The organism and the causal texture of the environment. Psychological Review, v. 42, n. 1, p. 43-77, 1935.

USTILOVSKAYA, A. A. Psychological mechanisms of overcoming the symbolic naturalization of the ideal content of geometric concepts. Moscow: Scientific research institute of secondary education development Innovative strategies, 2008.

YAKIMANSKAYA, I. S. Psychological foundations of mathematical education. Moscow: Akademia, 2004.

ZAKARIA, E.; LEE, L. S. Teacher's perceptions toward the use of GeoGebra in the teaching and learning of Mathematics. Journal of Mathematics and Statistics, v. 8, n. 2, p. 253-257, 2012.

ZEMLIAKOV, A. N. Psychodidactic aspects in-depth mathematics study in senior grades of secondary school. Mathematics. The First of September, n. 5, p. 8-10, 2005.

ZENGIN, Y.; FURKAN, H.; KUTLUCA, T. The effect of dynamic mathematics software GeoGebra on student achievement in teaching of trigonometry. Procedia: Social and Behavioral Sciences, v. 31, p. 183-187, 2012.

\section{How to reference this article}

PODAEVA, N. G.; AGAFONOV, P. A. Actualization of gifted schoolchildren's intentional experience in the process of mastering geometric concepts: from support to activity mechanism. Revista online de Política e Gestão Educacional, Araraquara, v. 16, n. 2, p. 1311-1327, May/Aug. 2021. e-ISSN: 1519-9029. DOI: https://doi.org/10.22633/rpge.v25i2.15449

Submitted: $10 / 05 / 2021$

Required revisions: $25 / 06 / 2021$

Approved: 20/07/2021

Published: 01/08/2021 